\title{
Phytochemical Screening, Free Radical Mitigation and Antidiabetic Potentials of Pentanisia prunelloides (Klotzsch ex Eckl. \& Zeyh.) Walp. Root Extracts
}

\author{
Fikile Nelly Makhubu ${ }^{1,2}$, Anofi Omotayo Tom Ashafa ${ }^{1, *}$, Gerda Fouchéé, Fatai Oladunni Balogun ${ }^{1}$ \\ ${ }^{1}$ Phytomedicine and Phytopharmacology Research Group, Department of Plant Sciences, \\ University of the Free State, Qwaqwa Campus, Private Bag X13, Phuthaditjhaba, 9866, South Africa \\ ${ }^{2}$ Natural Product and Agro processing, Biosciences Unit, Council for Scientific and Industrial Research, \\ P.O. Box 396, Pretoria, 0001, Gauteng, South Africa \\ *Corresponding author: ashafaaot@ufs.ac.za
}

Received April 04, 2019; Revised May 06, 2019; Accepted May 21, 2019

\begin{abstract}
Diabetes mellitus is attributed as one of the major health problems globally. This study evaluated the antioxidative and antidiabetic potentials of $P$. prunelloides in an in-vitro model and also screened for the presence of phytochemicals in the extracts. The antioxidant activity of the extracts (water, ethanol, aqueous-ethanol and hexane) was determined by superoxide anion, hydroxyl, 1,1-diphenyl-2-picrylhydrazyl (DPPH) radical scavenging assays and iron chelation method while the antidiabetic potential was assessed by determining the inhibitory effects of the extracts on the activities of $\alpha$-amylase, $\alpha$-glucosidase, maltase and sucrase enzymes. The hexane extract displayed significantly higher $(\mathrm{p}<0.05)$ inhibition of $\alpha$-amylase $(0.48 \mu \mathrm{g} / \mathrm{mL})$ and $\alpha$-glucosidase $(18.08 \mu \mathrm{g} / \mathrm{mL})$ respectively. Additionally, water extract demonstrated strong inhibition of sucrase $(3.85 \mu \mathrm{g} / \mathrm{mL})$, and aqueous-ethanol extract $(26.03 \mu \mathrm{g} / \mathrm{mL})$ on maltase activity when compared with other extracts and control. The Lineweaver Burke plot revealed the non-competitive inhibition of $\alpha$-amylase and $\alpha$-glucosidase by the ethanol extract. While hexane extract demonstrated significant $(\mathrm{p}<0.05)$ scavenging activities against superoxide anion $(0.33 \mu \mathrm{g} / \mathrm{mL})$ and hydroxyl radical $(0.51 \mu \mathrm{g} / \mathrm{mL})$, water $(75.42 \mu \mathrm{g} / \mathrm{mL})$ and aqueous-ethanol $(4.24 \mu \mathrm{g} / \mathrm{mL})$ extracts exhibited the strongest DPPH activity and iron chelation effect respectively. The phytochemical analysis of the extract revealed the presence of tannins, terpenoids, alkaloids, saponins, flavonoids and cardiac glycosides while quantification of phytochemicals revealed total flavonoids with $15.40 \mathrm{mg}$ quercetin equivalent $(\mathrm{QE}) / \mathrm{g}$ from hexane extract, highest tannin content with $45.60 \mathrm{mg}$ gallic acid equivalent (GAE)/g (aqueous-ethanol extract) and total phenol from water and aqueousextracts with $0.07 \mathrm{mg} \mathrm{GAE} / \mathrm{g}$ while alkaloids and saponins contents were found to be low in the roots of $P$. prunelloides, at 0.6 and $13.9 \%$ respectively. It can therefore be concluded that $P$. prunelloides extracts possessed antioxidant and antidiabetic activities in vitro and could thus be suggested that its mechanism of antidiabetic action is through the inhibition of diabetes-related enzymes.
\end{abstract}

Keywords: antidiabetic, antioxidants, P. prunelloides, phytochemicals, quantification

Cite This Article: Fikile Nelly Makhubu, Anofi Omotayo Tom Ashafa, Gerda Fouché, and Fatai Oladunni Balogun, "Phytochemical Screening, Free Radical Mitigation and Antidiabetic Potentials of Pentanisia prunelloides (Klotzsch ex Eckl. \& Zeyh.) Walp. Root Extracts.” Journal of Food and Nutrition Research, vol. 7, no. 5 (2019): 391-401. doi: 10.12691/jfnr-7-5-9.

\section{Introduction}

Diabetes mellitus (DM), a fast growing menace, is a chronic endocrine disorder that affects the metabolism of carbohydrates, fats, proteins, water and electrolytes [1]. It is considered as one of the non-curable illnesses controlled through the monitoring of the blood sugar level over healthy diet, exercise and medication [2]. There are several classes of DM but type II diabetes also known as non-insulin dependent diabetes mellitus (NIDDM) is regarded as the most common type affecting about $90 \%$ of the people worldwide [3]. Diabetes-induced metabolic dysfunction may be caused by the action of reactive oxygen species (ROS) produced in the mitochondrial electron transport chain [4]. The excessive levels of ROS such as the superoxide anion radical $\left(\mathrm{O}_{2}^{-}\right)$and hydroxyl radicals $\left(\mathrm{OH}^{-}\right)$have been linked to the onset of many diseases like cancer, stroke and diabetes [5,6]. Diabetes management can be through the use of drugs (oral hypoglycaemic agents, OHAs) but a very few of these recognized pharmaceutical drugs namely acarbose, voglibose and miglitol etc. have shown potentials in controlling hyperglycaemia. These drugs despite wide usage are often reported to cause several side effects including cramping, abdominal distention, flatulence and diarrhoea [7,8,9]. Therefore, the search for the discovery of antioxidant and 
antidiabetic agents from plant sources is an important strategy required to combat the widespread nature of this condition. Alpha-amylase and alpha-glucosidase are prominent enzymes that plays important roles in carbohydrate metabolism. They serves as one of the therapeutic approaches for decreasing postprandial hyperglycemia by slowly or delaying the digestion of carbohydrates by the inhibition of these enzymes in the digestive tract [10].

Pentanisia prunelloides, a perennial herb belonging to the Rubiaceae family is commonly called wild verbena (English), setimamollo (Sotho) translated as fire extinguisher, icimamlilo (Zulu) putting out the fire and sooibrandbossie (Afrikaans) little heartburn bush [11,12]. The roots and leaves of this plant are mostly used for treating a variety of ailments such as heartburn, fever, tuberculosis, blood impurities, haemorrhoids, toothache, chest pains, sore joints, swellings and snake bites [13,14]. The plant had been reported to be effective during pregnancy to ease childbirth; the leaf against retained placenta [15] and diarrhea as reported by Madikizela et al. [16] while the roots are used for managing gynaecological complaint such dysmenorrhoea [17]. Several studies have established that boiled grated dried bulb taken orally stops vomiting [18], the decoction of the bruised and boiled root mixed with sour milk are taken orally [19] for swelling of the stomach and the root extract for treating aches and pains [20]. The antibacterial compound, palmitic acid had been isolated from this plant by Yff et al. [21] and Madikizela et al. [22] also reported the antibacterial activity of some $P$. prunelloides extracts. The plant was also found to possess anti-inflammatory, antiviral and antioxidant activities by inhibiting cyclooxygenase-1 (COX-1), viral replication of the influenza A virus [21,23] and DPPH radicals through hydrogen transferring reactions [24]. Despite the several reports on the antioxidants and phytochemicals effectiveness of this plant, there exist insufficient information on the antioxidant with no report on antidiabetic potentials. Therefore, this study was carried out to evaluate the antioxidant and antidiabetic potentials of different extracts in an in-vitro model.

\section{Material and Methods}

\subsection{Plant Materials Collection and Authentication}

The plant material (roots) was collected naturally from a multi population in the eastern part of Free State near Golden Gate at Beste Farm in October 2015. The location was found at a mountainous area with the following coordinates: latitude $28^{\circ} 23^{\prime} 55.60^{\prime \prime} S$ and longitude $28^{\circ} 47^{\prime}$ 18.83" E. The plant was further authenticated by Dr. EJJ Sieben of Plant Sciences Department at the University of the Free State, Qwaqwa campus. The voucher specimen (MakMed 03/ 2015/ QHB) was prepared and deposited at the University herbarium.

\subsection{Extract Preparation}

The fresh root materials were separately rinsed under running water to remove debris and then dried in an
Ecotherm oven (Laboratory Consumables Pty, RSA) at a temperature of $45^{\circ} \mathrm{C}$ until constant weight was reached. The dried root material was ground using an electric blender (Nanning Mainline Food Machinery Company Ltd, China) to a powdered form and weighed. Exactly 20 $\mathrm{g}$ of the powdered root materials was separately extracted in four solvents (200 mL each) of different polarities namely hexane, ethanol, aqueous-ethanol (1:1) and distilled water (Aqueous). The flasks were placed on a Labcon platform shaker (Laboratory consumables, PTY, Durban, South Africa) at $115 \mathrm{rpm}$ for $24 \mathrm{~h}$. The extracted mixtures were filtered using Whatman No.1 (Whatman, UK) filter paper to obtain a homogenous mixture. The filtrates of the hexane, ethanol and aqueous-ethanol solvents were concentrated in a rotary evaporator at $45^{\circ} \mathrm{C}$ while the aqueous filtrate was placed in water bath at $45^{\circ} \mathrm{C}$ to obtain a dried extract. Extracts were dissolved in dimethysulphoxide (DMSO) to give stock solutions of 1.0 $\mathrm{mg} / \mathrm{mL}$ and different concentrations $(6.25,12.50,25.00$, 50.00 and $100.00 \mu \mathrm{g} / \mathrm{mL}$ ) of the extracts were prepared using a serial dilution method with distilled water. The leftover extracts were stored at $4^{\circ} \mathrm{C}$ until further use.

\subsection{Chemicals and Reagents}

Porcine pancreatic $\alpha$-amylase, rat intestinal $\alpha$-glucosidase, 1,1- diphenyl-2-picrylhydrazyl, gallic acid, quercetin, acarbose and para-nitrophenyl-glucopyranoside were products of Sigma-Aldrich Co., St. Louis, USA while starch soluble (extra pure) was obtained from J. T. Baker Inc., Phillipsburg, USA. Other chemicals and reagents were of analytical grade and the water used was glass-distilled.

\subsection{Evaluation of Antioxidant Activities}

\subsubsection{Superoxide Anion Radical Scavenging Ability}

The measurement of superoxide anion scavenging activity of the various extracts was based on the method described by Liu et al. [25]. Superoxide radicals were generated in $50 \mu \mathrm{L}$ of Tris- $\mathrm{HCl}$ buffer (16 mM, pH 8.0) containing $50 \mu \mathrm{L}$ of NBT ( $50 \mathrm{mM}$ ) solution, $50 \mu \mathrm{L}$ NADH (78 $\mathrm{mM})$ solution and different concentrations (6.25 $100 \mu \mathrm{g} / \mathrm{mL})$ of $P$. prunelloides extracts $(100 \mu \mathrm{L})$. The reaction started by adding $1 \mathrm{~mL}$ of phenazine methosulphate (PMS) solution $(10 \mathrm{mM})$ to the mixture. The reaction mixture was incubated at $25^{\circ} \mathrm{C}$ for $5 \mathrm{~min}$, and the absorbance was measured at $560 \mathrm{~nm}$. Superoxide anion radical scavenging ability of a standard antioxidant was also tested by replacing the extract with gallic acid (6.25-100 $\mu \mathrm{g} / \mathrm{mL})$. The percentage inhibition of the radical by the extract was calculated following the expression below:

$$
\text { \%Inhibition }=\frac{\text { Acontrol }- \text { Asample }}{\text { Acontrol }} \times 100
$$

Where Acontrol is the absorbance measurement of the control and Asample is the absorbance of the test sample (extract/standard).

\subsubsection{Hydroxyl Radical Scavenging Ability}

The ability of the root extracts of $P$. prunelloides to prevent $\mathrm{Fe}^{2+} / \mathrm{H}_{2} \mathrm{O}_{2}$-induced decomposition of deoxyribose 
was carried out using the modified method described by Oboh and Rocha [26]. Briefly, $40 \mu \mathrm{L}$ freshly prepared extracts $(6.25-100 \mu \mathrm{g} / \mathrm{mL})$ was added to the mixture containing $20 \mu \mathrm{L}(20 \mathrm{mM})$ deoxyribose, $80 \mu \mathrm{L}(0.1 \mathrm{M})$ phosphate buffer, $10 \mu \mathrm{L}(20 \mathrm{mM})$ hydrogen peroxide and $10 \mu \mathrm{L}(500 \mathrm{mM}) \mathrm{FeSO}_{4}$, afterwards, the volume was made up to $200 \mu \mathrm{L}$ with distilled water. The reaction mixture was incubate at $37^{\circ} \mathrm{C}$ for $30 \mathrm{~min}$ and stopped by the addition of $50 \mu \mathrm{L}$ of $2.8 \%$ TCA (trichloroacetic acid), followed by the addition of $50 \mu \mathrm{L}$ of $0.6 \%$ TBA solution. The mixtures were subsequently incubated for $20 \mathrm{~min}$, transferred to a 96-well microtiter plate before measuring the absorbance at $532 \mathrm{~nm}$ in a microplate reader (Model 680, BIO-RAD). Hydroxyl radical scavenging ability of a standard antioxidant was also tested by replacing the extract with gallic acid (6.25-100 $\mu \mathrm{g} / \mathrm{mL})$. Percentage inhibition determined following equation shown 1 above.

\subsubsection{DPPH Free Radical Scavenging Ability}

The free radical scavenging ability of the extracts against DPPH (1, 1-diphenyl-2-picrylhydrazyl) free radical was evaluated by a modified method of Saha et al. [27]. Different concentrations $(6.25-100 \mu \mathrm{g} / \mathrm{mL})$ of the extracts $(150 \mu \mathrm{L})$ were mixed with $150 \mu \mathrm{L}$ of $0.4 \mathrm{mmol} / \mathrm{L}$ methanolic solution containing DPPH radicals. The mixture was left in the dark for $30 \mathrm{~min}$ and the absorbance was measured at $516 \mathrm{~nm}$. The DPPH free radical scavenging ability of each extract was subsequently calculated with respect to the reference (which contains all the reagents without the test sample). DPPH free radical scavenging ability of a standard antioxidant was also tested by replacing the extract with ascorbic acid $(6.25-100 \mu \mathrm{g} / \mathrm{mL})$ and determined as percentage inhibition based on equation 1 above.

\subsubsection{Iron Chelation Assay}

The chelation of ferrous ions by the root extracts of $P$. prunelloides was determined by the modified method of Dorman et al. [28]. Briefly, $200 \mu \mathrm{L} \mathrm{FeCl}_{2}(0.2 \mathrm{mM})$ was added to $40 \mu \mathrm{L}$ aliquots of extracts $(6.25-100 \mathrm{mg} / \mathrm{mL})$. The reaction was initiated by the addition of $5 \mathrm{mM}$ ferrozine $(80 \mu \mathrm{L})$ in a 96-well plate, the mixture vigorously shaken and left to stand at room temperature for $10 \mathrm{~min}$. The absorbance was then measured at $562 \mathrm{~nm}$ in a microplate reader (Model 680, BIO-RAD, USA). Iron chelating potential of a standard antioxidant was also tested by replacing the extract with gallic acid (6.25-100 $\mu \mathrm{g} / \mathrm{mL})$ while calculating the percentage inhibition as above (equation 1).

\subsection{Determination of Antidiabetic Potentials}

\subsubsection{Alpha-glucosidase Inhibitory Activity}

The effect of the plant extract on $\alpha$-glucosidase activity was determined according to the method described by Adisakwattana et al. [29] with modifications. The substrate solution p-nitrophenyl glucopyranoside (pNPG), sucrose $(50 \mathrm{mM})$ and maltose $(25 \mathrm{mM})$ were prepared in $0.02 \mathrm{M}$ phosphate buffer $(\mathrm{pH} 6.9), 100 \mu \mathrm{L}$ of glucosidase $(0.5 \mathrm{mg} / \mathrm{mL})$ was pre-incubated with $50 \mu \mathrm{L}$ of the different concentrations $(6.25-100 \mu \mathrm{g} / \mathrm{mL})$ of the extracts for $10 \mathrm{~min}$. Then $50 \mu \mathrm{L}$ of $5 \mathrm{mM}$ (pNPG), maltose and sucrose in $0.02 \mathrm{M}$ phosphate buffer ( $\mathrm{pH}$ 6.9) was individually added to start the reaction. The reaction mixture was incubated at $37{ }^{\circ} \mathrm{C}$ for $20 \mathrm{~min}$ and stopped by adding $2 \mathrm{~mL}$ of $0.1 \mathrm{M} \mathrm{Na}_{2} \mathrm{CO}_{3}$. The enzyme activities (alpha-glucosidase, sucrase and maltase) were determined by measuring the yellow coloured para-nitrophenol released from pNPG and absorbance at $405 \mathrm{~nm}$ ( $\alpha$-glucosidase) or $540 \mathrm{~nm}$ (maltase and sucrase) using micro plate titre reader (Model 680, BIO-RAD). The control was prepared using the same procedure replacing the extract with distilled water while the activity of the standard was evaluated by replacing the extract with acarbose $(6.25-100 \mu \mathrm{g} / \mathrm{mL})$. Percentage inhibition was calculated, thus;

$$
\% \text { Inhibition }=\frac{\Delta \text { Acontrol }-\Delta \text { Asample test }}{\Delta \text { Acontrol }} \times 100
$$

Where $\Delta$ Acontrol $=$ Acontrol - Ablank and $\Delta$ Asample $=$ Asample - Ablank. The sample test is extract and the concentrations of extracts resulting in 50\% inhibition of enzyme activity $\left(\mathrm{IC}_{50}\right)$ were determined graphically.

\subsubsection{Mode of $\alpha$-glucosidase Inhibition}

The mode of inhibition of $\alpha$-glucosidase by the extract was determined using the extract with the most potent hypoglycaemic result according to the modified method described by Ali et al. [30]. Ethanol extract was selected based on its mild inhibition against alpha-amylase (highest $\mathrm{IC}_{50}$ value) and strongest alpha-glucosidase inhibition (lowest $\mathrm{IC}_{50}$ value) as compared to the other extracts. Briefly, $50 \mu \mathrm{L}$ of the $(5 \mathrm{mg} / \mathrm{mL})$ ethanol extract was preincubated with $100 \mu \mathrm{L}$ of $\alpha$-glucosidase solution for 10 $\min$ at $25^{\circ} \mathrm{C}$ in one set of five test tubes. In another set of tubes, $\alpha$-glucosidase was pre-incubated with $50 \mu \mathrm{L}$ of phosphate buffer ( $\mathrm{pH}$ 6.9). $50 \mu \mathrm{L}$ of $\mathrm{pNPG}$ at increasing concentrations $(0.20-1.0 \mu \mathrm{g} / \mathrm{mL})$ was added to both sets of reaction mixtures to start the reaction. The mixture was then incubated for $10 \mathrm{~min}$ at $25^{\circ} \mathrm{C}$ and $500 \mu \mathrm{L}$ of $\mathrm{Na}_{2} \mathrm{CO}_{3}$ was added to stop the reaction.

The amount of reducing sugars released was determined spectrophotometrically using a para-nitrophenol standard curve and converted to reaction velocities. A double reciprocal (Lineweaver-Burk) plot (1/v versus $1 /[\mathrm{S}]$ ) where $\mathrm{v}$ is reaction velocity and [S] is substrate concentration was plotted to determine the mode of inhibition.

\subsubsection{Alpha-amylase Inhibitory Activity}

The assay was carried-out using the modified procedure of McCue and Shetty [31]. Briefly, $50 \mu \mathrm{L}$ extract was placed in a tube and $50 \mu \mathrm{L}$ of $0.02 \mathrm{M}$ sodium phosphate buffer ( $\mathrm{pH}$ 6.9) containing $\alpha$-amylase solution $(0.5 \mathrm{mg} / \mathrm{mL})$ was added. This solution was pre-incubated at $25^{\circ} \mathrm{C}$ for $10 \mathrm{~min}$, after which $50 \mu \mathrm{L}$ (1\%) starch solution in $0.02 \mathrm{M}$ sodium phosphate buffer ( $\mathrm{pH}$ 6.9) was added and then further incubated at $25^{\circ} \mathrm{C}$ for $10 \mathrm{~min}$. The reaction was terminated by adding $200 \mu \mathrm{L}$ of dinitrosalicylic acid (DNS) reagent. The tubes were then incubated in boiling water for $10 \mathrm{~min}$ and cooled at room temperature. The reaction mixture was diluted with $300 \mu \mathrm{L}$ of distilled water and the absorbance was measured at $540 \mathrm{~nm}$ using micro plate titre reader (Model 
680, BIO- RAD). A control was prepared using the same procedure replacing the sample test with distilled water. The $\alpha$-amylase inhibitory activity was calculated as percentage inhibition following the expression shown in equation 2.

\subsubsection{Mode of $\alpha$-amylase Inhibition}

The mode of inhibition of $\alpha$-amylase by ethanol extract of the plant was conducted according to the modified method described by Ali et al. [30]. Briefly, $250 \mu \mathrm{L}$ of the ( $5 \mathrm{mg} / \mathrm{mL}$ ) extract was pre-incubated with $250 \mu \mathrm{L}$ of $\alpha$-amylase solution for $10 \mathrm{~min}$ at $25^{\circ} \mathrm{C}$ in one set of tubes. In another set of tubes, $\alpha$-amylase $(250 \mu \mathrm{L})$ was pre-incubated with $250 \mu \mathrm{L}$ of phosphate buffer ( $\mathrm{pH}$ 6.9). $250 \mu \mathrm{L}$ of starch solution (1\%) at increasing concentrations $(0.20-1.0 \mu \mathrm{g} / \mathrm{mL})$ was added to both sets of reaction mixtures to start the reaction. The mixture was then incubated for $10 \mathrm{~min}$ at $25^{\circ} \mathrm{C}$, boiled for $5 \mathrm{~min}$ after addition of $500 \mu \mathrm{L}$ of DNS to stop the reaction. The amount of reducing sugars released was determined spectrophotometrically using maltose standard curve converted to reaction velocities. A double reciprocal (Lineweaver-Burk) plot (1/v versus $1 /[\mathrm{S}])$ where $\mathrm{v}$ is reaction velocity and [S] is substrate concentration was plotted to determine the mode of inhibition.

\subsection{Qualitative Analysis of Secondary Metabolites}

Phytochemical composition of the plant extracts were determined by the methods described by Trease and Evans [32] and Sofowora [33].

\subsubsection{Test for Tannins}

To $0.5 \mathrm{~mL}$ of the extract solution, $1 \mathrm{~mL}$ of distilled water and one to two drops of ferric chloride solution were added and observed for brownish green or a blue colouration confirming the presence of tannins

\subsubsection{Test for Terpenoids}

A $5 \mathrm{~mL}$ of extract was mixed with $2 \mathrm{~mL}$ of chloroform in a test tube. Thereafter, $3 \mathrm{~mL}$ of concentrated $\mathrm{H}_{2} \mathrm{SO}_{4}$ was carefully added to the mixture to form a layer. An interface reddish brown colouration was formed indicating the presence of terpenoids

\subsubsection{Test for Alkaloids}

A $1 \mathrm{~mL}$ of $1 \% \mathrm{HCl}$ was added to $3 \mathrm{~mL}$ of extract in a test tube and was treated with few drops of Meyer's reagent. A creamy white precipitate indicated the presence of alkaloids

\subsubsection{Test for Saponins}

A $5 \mathrm{~mL}$ of extract was shaken vigorously to obtain a stable persistent froth. The frothing was then mixed with three drops of olive oil and observed for the formation of emulsion, which indicated the presence of saponins.

\subsubsection{Test for Flavonoids}

A few drops of $1 \% \mathrm{NH}_{3}$ solution was added to the extract in a test tube. A yellow colouration was observed for the presence of flavonoids.

\subsubsection{Test for Cardiac Glycosides}

A $5 \mathrm{~mL}$ of extract was mixed with glacial acetic acid containing one drop of ferric chloride. The above mixture was carefully added to the $1 \mathrm{~mL}$ of concentrated $\mathrm{H}_{2} \mathrm{SO}_{4}$. The presence of cardiac glycosides was detected by the formation of brown ring.

\subsubsection{Test for Phlobotannins}

About $10 \mathrm{~mL}$ of extract was boiled with $1 \% \mathrm{HCl}$ in boiling tube. Deposition of red precipitate indicated the presence of phlobatannins.

\subsection{Quantitative Analysis of Secondary Metabolites}

\subsubsection{Quantitative Analysis of Secondary Metabolites}

To a $250 \mathrm{~mL}$ beaker, $5 \mathrm{~g}$ of sample was mixed with 200 $\mathrm{mL}$ of $10 \%$ acetic acid in ethanol and the mixture was allowed to stand for $4 \mathrm{~h}$. The filtrates were collected and concentrated on a water bath to one-quarter of the original volume. Afterwards, concentrated ammonium hydroxide was added drop wise until precipitation was complete. The solution was allowed to settle and the precipitate was collected and washed with dilute ammonium hydroxide and then filtered. The residue, alkaloid, were dried through evaporation of solvent and weighed [34]. Percentage yield of the extract is defined as the total dry mass after evaporation and was calculated using equation:

$$
\begin{aligned}
& \% \text { Yield } \\
& =\frac{\text { Mass of dry weight }(g)}{\text { Total mass of dry powdered sample }(g)} \times 100
\end{aligned}
$$

\subsubsection{Determination of Total Saponins Content}

Ten grams of the powdered material was extracted in $100 \mathrm{~mL}$ of $20 \%$ aqueous-ethanol.

The mixture was heated over a hot water bath for $4 \mathrm{~h}$ with continuous stirring at about $55^{\circ} \mathrm{C}$, this was followed by filtration. The residue was re-extracted

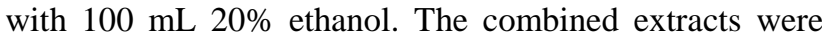
reduced to $40 \mathrm{~mL}$ over water bath at about $90{ }^{\circ} \mathrm{C}$. The concentrate was transferred into a $250 \mathrm{~mL}$ separation funnel and $20 \mathrm{~mL}$ of diethyl ether was added and shaken vigorously. The aqueous layer was recovered while the ether layer was discarded. This purification process was repeated two times until $60 \mathrm{~mL}$ of $\mathrm{n}$ - butanol was then added to the extract. The n-butanol extracts was washed twice with $10 \mathrm{~mL}$ of $5 \%$ aqueous sodium chloride. The remaining solution after washing was heated in a water bath [35]. Following evaporation, the samples were dried in an oven to a constant weight and the saponin content was then calculated as illustrated above (equation 3).

\subsubsection{Determination of Total Tannins Content}

The total tannins content of the roots extracts of $P$. prunelloides was determined by Folin-Ciocalteu method as described by Miean and Mohamed [36]. In $10 \mathrm{~mL}$ volumetric flask, $0.1 \mathrm{~mL}$ of extract was mixed with $7.5 \mathrm{~mL}$ of distilled water followed by $0.5 \mathrm{~mL}$ of Folin-Ciocalteu phenol reagent and $1 \mathrm{~mL}$ of $35 \% \mathrm{Na}_{2} \mathrm{CO}_{3}$ 
solution further diluted to $10 \mathrm{~mL}$ with distilled water. The mixture was shaken well and kept at room temperature for $30 \mathrm{~min}$. A set of reference standard solutions of gallic acid $(20,40,60,80$ and $100 \mu \mathrm{g} / \mathrm{mL})$ were prepared. Absorbance for test and standard solutions were measured against the blank at $725 \mathrm{~nm}$ with Biowave II (Biochrom, United Kingdom) spectrophotometer. The tannin content was expressed in terms of mg of gallic acid equivalent (GAE) /g of extract. A standard curve of absorbance against gallic acid concentration was prepared and results were expressed as percentage $\mathrm{w} / \mathrm{w}$ i.e. tannin content $(\% \mathrm{w} / \mathrm{w})=\mathrm{GAE} \times \mathrm{V} \times \mathrm{D} \times 10-3 \times 100$ where GAE - gallic acid equivalent $(\mu \mathrm{g} / \mathrm{mL}), \mathrm{V}$ - total volume of sample $(\mathrm{mL})$, $\mathrm{D}$-dilution factor

\subsubsection{Determination of Total Flavonoids}

Ten milligrams of quercetin was dissolved in $100 \mathrm{~mL}$ of methanol $(100 \mu \mathrm{g} / \mathrm{mL})$ and then further diluted to 10 , 20, 40, 80 or $160 \mu \mathrm{g} / \mathrm{mL}$ [37]. The diluted standard solutions $(0.5 \mathrm{~mL})$ were separately mixed with $1.5 \mathrm{~mL}$ of methanol, $0.1 \mathrm{~mL}$ of aluminium chloride $\left(\mathrm{AlCl}_{3}\right)(10 \%)$, $0.1 \mathrm{~mL}$ of $1 \mathrm{M}$ potassium acetate and $2.8 \mathrm{~mL}$ of diluted water. After incubation at room temperature for $30 \mathrm{~min}$, the absorbance of the reaction mixture was measured at $415 \mathrm{~nm}$ using a Biowave II (Biochrom, UK) spectrophotometer. The amount of $\mathrm{AlCl}_{3}$ (10\%) was substituted by the same amount of distilled water in blank. Quantification was done based on the standard curve of quercetin.

A standard curve of absorbance against quercetin concentration was prepared and results were expressed as percentage $\mathrm{w} / \mathrm{w}$ i.e. flavonoids content $(\% \mathrm{w} / \mathrm{w})=$ $\mathrm{QE} \times \mathrm{V} \times \mathrm{D} \times 10-3 \times 100$ where $\mathrm{QE}$ is quercetin equivalent, $\mathrm{V}$ is sample total volume and $\mathrm{D}$ is the dilution factor.

\subsubsection{Determination of Total Phenolic Content}

Total phenol content in the plant extract was determined by the method of Singleton et al. [38] with modification of Folin-Ciocalteu by Wolfe et al. [39]. $50 \mu \mathrm{L}$ of aliquot extract $(1 \mathrm{mg} / \mathrm{mL})$ was mixed with $50 \mu \mathrm{L}$ of Folin-Ciocalteu reagent $(10 \%)$ and $50 \mu \mathrm{L}$ of water. $150 \mu \mathrm{L}$ of $7.5 \% \mathrm{Na}_{2} \mathrm{CO}_{3}$ was added to neutralize the reaction. The tubes were mixed thoroughly and incubated for $40 \mathrm{~min}$ at $45^{\circ} \mathrm{C}$. Absorbance was then measured at $765 \mathrm{~nm}$ using a Biowave II (Biochrom, UK) spectrophotometer. The total phenolic content was expressed as $\mathrm{mg} / \mathrm{mL}$ gallic acid adopting the equation obtained from calibration curve (using $0.05 \mathrm{mg} / \mathrm{mL}-0.5$ $\mathrm{mg} / \mathrm{mL}$ of gallic acid).

A standard curve of absorbance against gallic acid concentration was prepared and results were expressed as percentage $\mathrm{w} / \mathrm{w}$ i.e. phenolic content (\% w/w) $=\mathrm{GAE} \times \mathrm{V} \times \mathrm{D} \times 10-3 \times 100$ where $\mathrm{GAE}-$ gallic acid equivalent $(\mu \mathrm{g} / \mathrm{mL}), \mathrm{V}$ - total volume of sample $(\mathrm{mL})$, $\mathrm{D}$ - dilution factor.

\subsection{Statistical Analysis}

Statistical analysis was performed using GraphPad Prism 5 statistical package (Graph Pad Software, USA). The data were analyzed by one-way analysis of variance (ANOVA) followed by Bonferroni test. All the results were expressed as mean \pm standard error of mean (SEM) of triplicate determinations.

\section{Results}

\subsection{Antioxidant Assays}

The radical scavenging abilities of the root extracts of P. prunelloides are shown in Table 1 and Figure 1 . It was observed that going by half-maximal inhibitory concentration, hexane extract reveal the best significant $(p<0.05)$ activities in superoxide anion $(0.33 \mu \mathrm{g} / \mathrm{mL})$ and hydroxyl $(0.51 \mu \mathrm{g} / \mathrm{mL})$ when compared with other extracts and the control (55.50 and $65.70 \mu \mathrm{g} / \mathrm{mL}$ respectively). The DPPH evaluation revealed water extract $(75.42 \mu \mathrm{g} / \mathrm{mL})$ showing the best effect $(\mathrm{p}<0.05)$ while aqueous-ethanol $(4.24 \mu \mathrm{g} / \mathrm{mL})$ was the best chelator of metal ions. These activities are dose dependent for all the extracts and control (gallic acid) although at the highest concentration of $100 \mu \mathrm{g} / \mathrm{mL}$, gallic acid reflected the highest peak inhibition of superoxide and hydroxyl radicals as well as ascorbic acid against DPPH (Figure 1).

\subsection{Antidiabetic Assays}

Table 2 established the strongest inhibition of alpha-amylase $(0.48 \mu \mathrm{g} / \mathrm{mL})$ and alpha-glucosidase $(18.08 \mu \mathrm{g} / \mathrm{mL})$ by hexane extract while aqueous (3.85 $\mu \mathrm{g} / \mathrm{mL})$ and aqueous- ethanol $(26.03 \mu \mathrm{g} / \mathrm{mL})$ extracts best-inhibited $(\mathrm{p}<0.05)$ the activities of sucrase and maltase respectively in comparison with other extracts and acarbose. As witnessed with radical scavenging evaluations, the inhibition of the extracts and control are dose- dependent (Figure 2). The result of mode inhibition of the enzymes as obtained from Lineweaver Burke plot (Figure 3) by the ethanol extract depicts a non-competitive inhibition of alpha-glucosidase and a mixed non-competitive inhibition of alpha-amylase.

Table 1. IC $_{50}$ values for the diabetes-related enzymes' inhibitory potentials of different extracts of $P$. prunelloides

\begin{tabular}{|c|c|c|c|c|}
\hline \multirow[t]{2}{*}{ Samples } & \multicolumn{3}{|c|}{$\mathrm{IC}_{50}(\mu \mathrm{g} / \mathrm{mL})$} & \multirow[b]{2}{*}{$\alpha$-amylase } \\
\hline & $\alpha$-glucosidase & Sucrase & Maltase & \\
\hline Water & $36.01 \pm 6.21^{\mathrm{a}}$ & $3.85 \pm 2.11^{\mathrm{a}}$ & $90.49 \pm 2.90^{\mathrm{a}}$ & $8.82 \pm 0.53^{\mathrm{a}}$ \\
\hline Ethanol & $19.73 \pm 1.53^{\mathrm{b}}$ & $51.48 \pm 5.31^{\mathrm{b}}$ & $44.84 \pm 1.88^{c}$ & $18.51 \pm 1.78^{\mathrm{c}}$ \\
\hline Aqueous-ethanol & $40.33 \pm 0.49^{\mathrm{a}}$ & $64.36 \pm 0.84^{c}$ & $26.03 \pm 0.33^{b}$ & $9.03 \pm 2.08^{\mathrm{a}}$ \\
\hline Hexane & $18.08 \pm 0.03^{\mathrm{b}}$ & $61.66 \pm 1.43^{\mathrm{c}}$ & $31.59 \pm 2.81^{\mathrm{b}}$ & $0.48 \pm 0.35^{\mathrm{b}}$ \\
\hline Acarbose & $129.4 \pm 5.11^{c}$ & $30.65 \pm 1.13^{\mathrm{d}}$ & $122.1 \pm 4.64^{\mathrm{d}}$ & $9.87 \pm 1.61^{\mathrm{a}}$ \\
\hline
\end{tabular}

The values are expressed as mean \pm standard error of mean (SEM) of triplicate determinations ( $\mathrm{n}=3$ ). Means not sharing a common superscript for each enzyme are significantly different $(\mathrm{p}<0.05)$. Acarbose is the standard for $\alpha$-glucosidase and $\alpha$-amylase inhibitor. 

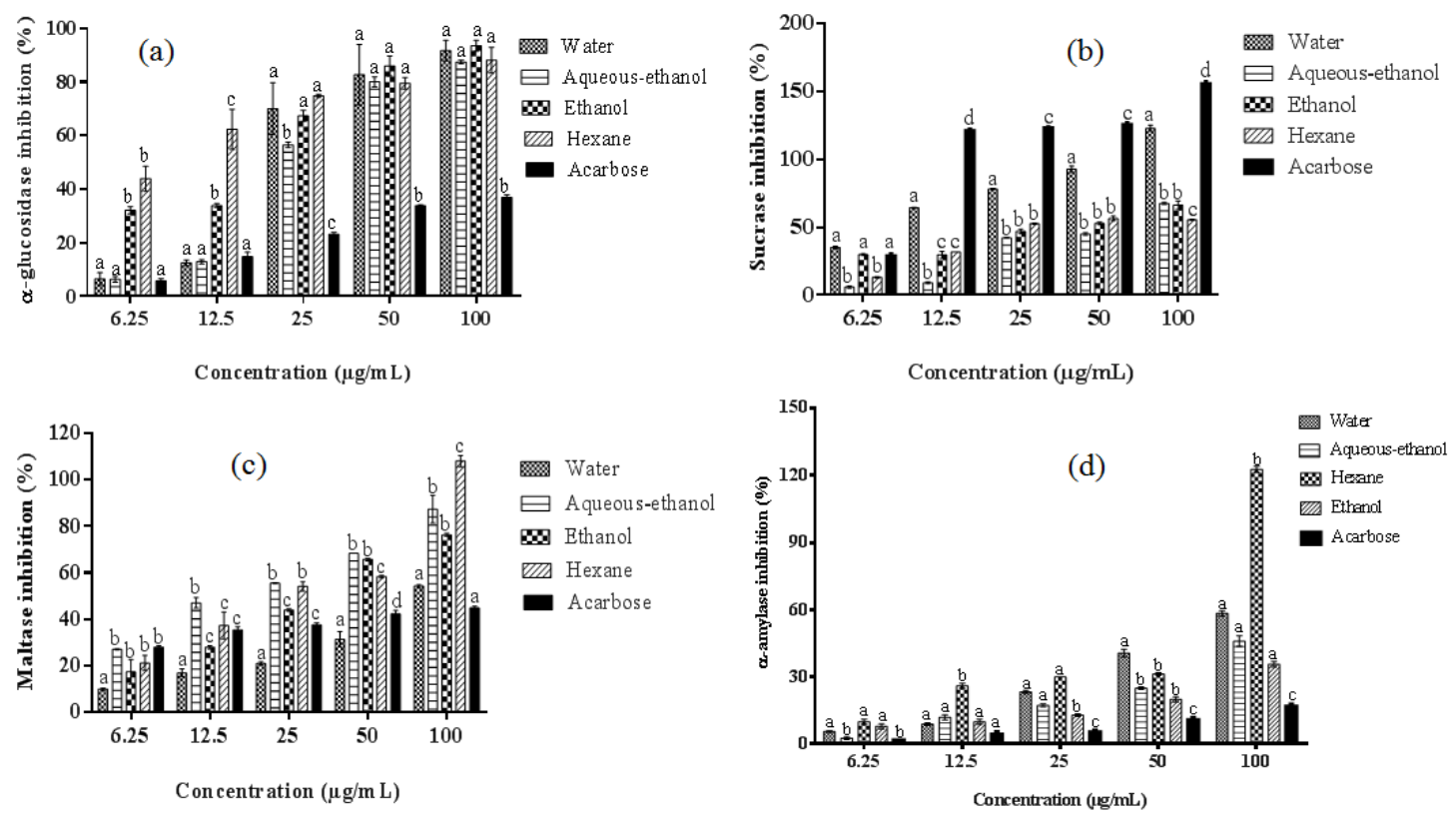

Figure 1. Inhibitory effects of different extracts of $P$. prunelloides on the activities of (a) $\alpha$-glucosidase, (b) sucrase, (c) maltase and (d) $\alpha$-amylase. Values are expressed as mean \pm standard error of mean (SEM) of triplicate determinations. Means not sharing a common letter at the same concentration
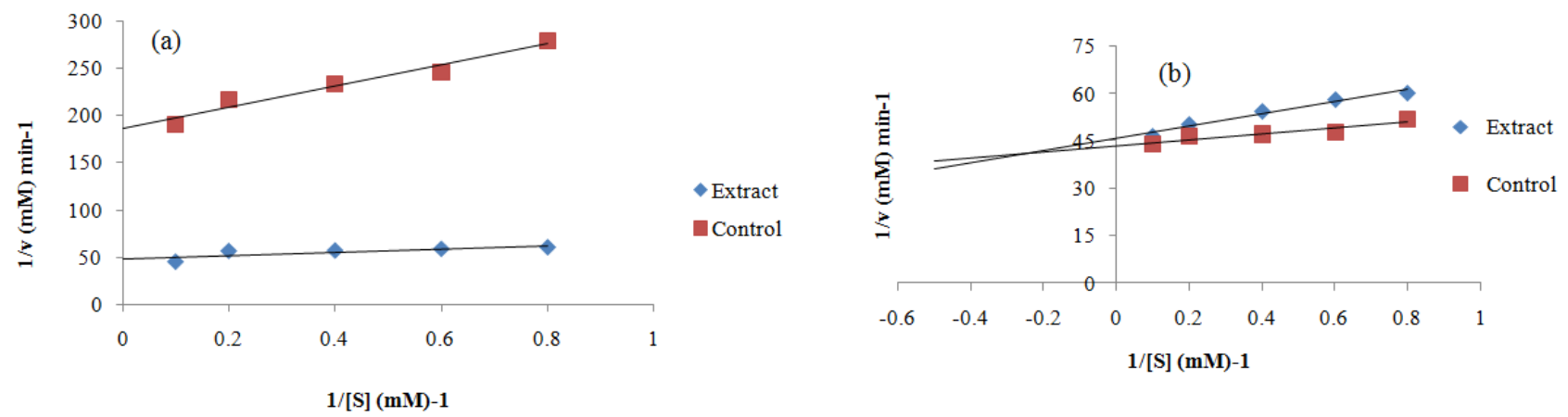

Figure 2. Lineweaver-Burk plot of $P$. prunelloides ethanol extract showing (a) non-competitive and (b) mixed non-competitive inhibition against $\alpha$ glucosidase and $\alpha$-amylase respectively
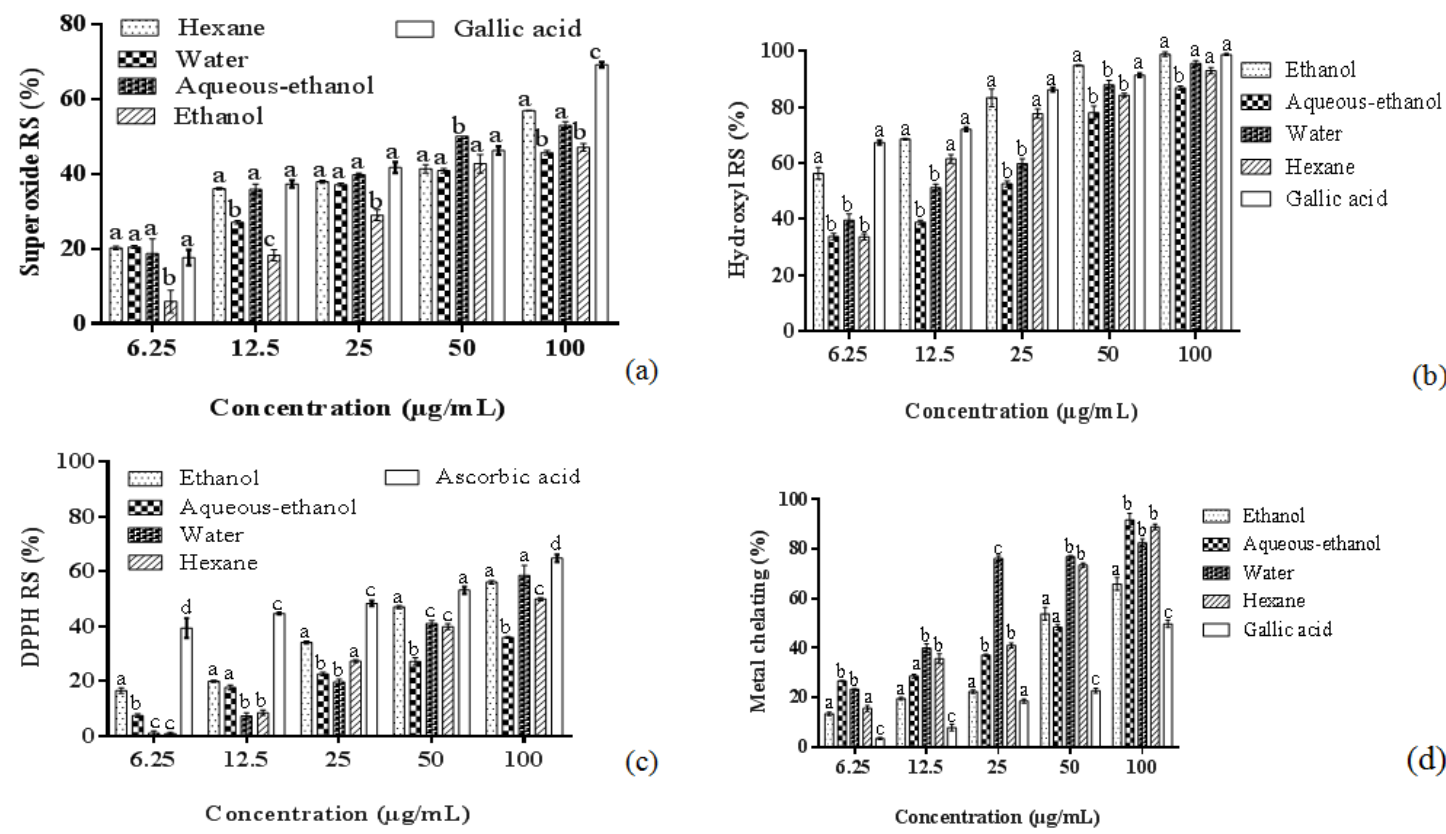

Figure 3. Scavenging abilities of different extracts of P. prunelloides against (a) superoxide, (b) hydroxyl, (c) 1,1-diphenyl-2-picrylhydrazyl (DPPH) radical anion and (d) metal chelation. Values are expressed as standard error of mean (SEM) of triplicate determinations. Bars not sharing a common letter at the same concentration are significantly different $(\mathrm{p}<0.05)$ 
Table 2. $\mathrm{IC}_{50}$ values for the free radical scavenging abilities of different extracts of Pentanisia prunelloides

\begin{tabular}{ccccc}
\hline \multirow{2}{*}{ Samples } & \multicolumn{3}{c}{$\mathbf{I C}_{50} \mathbf{( \mu g / \mathbf { m L } )}$} \\
\cline { 2 - 5 } & Superoxide & Hydroxyl & DPPH & Iron Chelation \\
\hline Ethanol & $92.98 \pm 1.20^{\mathrm{a}}$ & $42.99 \pm 1.50^{\mathrm{a}}$ & $77.06 \pm 0.22^{\mathrm{a}}$ & $64.86 \pm 3.20^{\mathrm{a}}$ \\
Aqueous-ethanol & $74.72 \pm 1.94^{\mathrm{b}}$ & $24.78 \pm 0.72^{\mathrm{b}}$ & $142.7 \pm 0.47^{\mathrm{b}}$ & $4.24 \pm 0.03^{\mathrm{b}}$ \\
Water & $118.7 \pm 0.66^{\mathrm{c}}$ & $12.28 \pm 0.51^{\mathrm{c}}$ & $75.42 \pm 2.28^{\mathrm{a}}$ & $20.30 \pm 1.56^{\mathrm{c}}$ \\
Hexane & $0.33 \pm 0.02^{\mathrm{d}}$ & $0.51 \pm 0.43^{\mathrm{d}}$ & $88.67 \pm 1.57^{\mathrm{c}}$ & $37.47 \pm 0.19^{\mathrm{d}}$ \\
Gallic Acid & $55.50 \pm 0.12^{\mathrm{e}}$ & $65.70 \pm 1.48^{\mathrm{e}}$ & $34.03 \pm 1.56^{\mathrm{d}}$ & $101.7 \pm 2.26^{\mathrm{e}}$ \\
\hline
\end{tabular}

The values are expressed as mean \pm SEM of triplicate determinations $(n=3)$. Means not sharing a common superscript are significantly different $(\mathrm{p}<0.05)$.

Table 3. The phytochemical constituents of extracts of $P$. prunelloides roots

\begin{tabular}{lcccc}
\hline Phytochemical type & Water & Ethanol & Hexane & Aqueous-ethanol \\
\hline Tannins & + & + & + & + \\
Terpenoids & + & + & - & + \\
Alkaloids & + & + & + & - \\
Saponins & + & + & - & - \\
Flavonoids & - & - & - \\
Cardiac glycosides & - & - & - \\
Phlobatannins & - & & + \\
\hline
\end{tabular}

(+) detected, (-) not detected.

Table 4. The quantitative analysis of phytochemicals of extracts of $P$. prunelloides roots

\begin{tabular}{ccc}
\hline Phytochemical type & Mass extracted (g) & \% yield \\
\hline Alkaloids & 0.03 & 0.6 \\
Saponins & 1.39 & 13.9 \\
\hline
\end{tabular}

Table 5. Total flavonoids, total tannins and total phenols of the root extracts of $P$. prunelloides

\begin{tabular}{cccc}
\hline Extracts & $\begin{array}{c}\text { Total flavonoids } \\
\text { (expressed in mg/g quercetin) }\end{array}$ & $\begin{array}{c}\text { Tannins } \\
\text { (expressed in mg/g gallic acid) }\end{array}$ & $\begin{array}{c}\text { Total phenols } \\
\text { (expressed in mg/g gallic acid) }\end{array}$ \\
\hline Water & $14.70 \pm 0.06^{\mathrm{a}}$ & $27.54 \pm 0.03^{\mathrm{a}}$ & $0.07 \pm 0.002^{\mathrm{a}}$ \\
Ethanol & $13.21 \pm 0.14^{\mathrm{b}}$ & $34.87 \pm 0.04^{\mathrm{a}}$ & $0.04 \pm 0.003^{\mathrm{b}}$ \\
Aqueous-ethanol & $13.74 \pm 0.01^{\mathrm{b}}$ & $45.60 \pm 0.05^{\mathrm{b}}$ & $0.07 \pm 0.002^{\mathrm{a}}$ \\
Hexane & $15.40 \pm 0.17^{\mathrm{a}}$ & $30.21 \pm 0.08^{\mathrm{a}}$ & $0.04 \pm 0.000^{\mathrm{b}}$ \\
\hline
\end{tabular}

Values are presented as mean \pm standard error of mean (SEM) ( $\mathrm{n}=3)$. Values with different superscript in the same column for each parameter are significantly different $(\mathrm{p}<0.05)$ to each other.

\subsection{Phytochemical Screening}

The results of the chemical groups' detection are presented in Table 3. It was observed that tannins, terpenoids and saponins were present while phlobatannins was absent in all the extracts. Alkaloids, flavonoids and cardiac glycosides were only detected in water, ethanol and aqueous-ethanol extracts respectively. The results of the quantitative determination of saponins and alkaloids are presented in Table 4 while those of the total flavonoids, tannins and phenolics are shown in Table 5. The roots of $P$. prunelloides were found to be very low in alkaloids (0.6), moderate with saponins (13.9) percentage yields.

The highest total flavonoids, tannins and phenols contents in all the extracts were significantly $(\mathrm{p}<0.05)$ witnessed with hexane (15.40 mg quercetin/g), aqueous-ethanol (mg/g $\mathrm{GAE}$ ) and aqueous (mg/g GAE) extracts respectively.

\section{Discussion}

One of the important strategies for the management of diabetes mellitus is to maintain a near normal blood glucose levels in fasting and postprandial conditions [40,41]. According to Rhabasa-Lhoret and Chiasson [42], inhibition of the activity of $\alpha$-amylase and $\alpha$-glucosidase delays the degradation of carbohydrate, which in turn decreases the absorption of glucose into tissues, thus, leading to reduction in postprandial blood glucose level. Acarbose and miglitol are $\alpha$-glucosidase inhibitors which act competitively by modulating the postprandial digestion and absorption of glucose $[43,44]$. However, the problem with these inhibitors is the resultant gastrointestinal discomfort such as flatulence and diarrhoea [9].

All the extracts (water, ethanol, aqueous-ethanol and hexane) investigated in this study demonstrated significant potency in inhibiting the activities of $\alpha$-amylase and $\alpha$ - glucosidase. The strongest inhibitory activities of the extracts (particularly hexane) on the $\alpha$-amylase is in agreement with previous reports by Balogun and Ashafa [45] which indicated that excessive inhibition of pancreatic $\alpha$-amylase could result in the abnormal bacterial fermentation of undigested carbohydrates in the colon $[46,47]$. Although $\alpha$-amylase inhibitory activity had positive effects on prevention of hyperglycemia linked to type II diabetes mellitus, however, mild inhibitory activity is desirable. Hence the ethanol extract was found to be the most suitable of the extracts showing mild/moderate activity in inhibiting this enzyme thus, the reason for being selected in order to study the kinetics of inhibition of the enzyme and this is similar to the report from Balogun and Ashafa [45] for D. anomala roots. The mode 
of inhibition of the enzyme indicated a mixed non-competitive type of inhibition suggesting that the active components in the extract did not compete with the substrate at binding at the active site of the enzyme. However, binds to a separate site to retard the conversion of oligosaccharides to disaccharides [48].

Alpha-glucosidases are intestinal enzymes catalysing the conversion of disaccharides to monosaccharides. Maltase and sucrase are forms of $\alpha$-glucosidases which catalyse the hydrolysis of maltose and sucrose to their constituent monosaccharides respectively [49]. The best activity of hexane and ethanol extracts (lower IC $_{50}$ values) against $\alpha$-glucosidase (Table 2) is suggestive of the hypoglycaemic effect of the plant and this could be attributed to the presence of the phytochemicals (phenolic compounds) present in the extracts (Table 3 and Table 5). In fact, a number of studies had submitted the antidiabetic effect of medicinal plants to be linked to the presence of polyphenolic compounds such as flavonoids [50-53], tannins $[54,55,56]$, etc. Interestingly, the strong inhibition witnessed by these extracts hexane, water, aqueous-ethanol against these enzymes alpha-glucosidases, sucrase and maltase respectively favours both polar and non-polar solvents thus, suggest inhibition by both polar and non-polar antihyperglycaemic compounds. This agrees with the reports from Kwon et al. [57] that natural $\alpha$-glucosidase inhibitors from medicinal plants show strong inhibitory activity against $\alpha$-glucosidase and therefore can be potentially used as an effective therapy for the management of postprandial hyperglycemia with minimal side effects. The kinetics of inhibition following Lineweaver-Burk plot established the non-competitive inhibition of $\alpha$-glucosidase suggesting that the active components of the extract binds to a site other than the active site of the enzyme and combine either with free enzyme or enzyme substrate complex possibly interfering with the action of both [58], thus, indicating the slowing down of disaccharides to monosaccharides.

Antioxidants are endowed with the responsibility of fighting against free radicals protects the body's defence mechanism from various diseases [59]. Many synthetic drugs may control oxidative damage but these drugs are associated with adverse side effects [60]. Hence, the antioxidant activities of plants may come handy in preventing the excessive production of free radicals by neutralizing their effects and or scavenge them when produced in the body or chelate the transition metal composition [61]. Ascorbic acid (vitamin C) is a water-soluble micronutrient required for multiple biological functions [62]. Gallic acid is an antioxidant used as a remote astringent in cases of internal haemorrhage as well as in the treatment of albuminuria and diabetes [63]. Dai and Mumper [64] reported that natural antioxidants are more effective than the synthetic ones such as vitamin $\mathrm{C}$, tocopherol etc., hence the need to evaluate the radical scavenging effects of potential antioxidative medicinal plants becomes germane.

In this present evaluation, the extracts scavenged superoxide uniformly at all concentrations, except at high concentration where the standard (gallic acid) had strong inhibition (Figure 1). The ability of the root extracts of $P$. prunelloides to inhibit this radical agrees with the findings of Giacco and Brownlee [65] and Khan et al. [66] suggesting the possibility of plant in reducing the production of superoxide while alleviating the potential damaging effects of the cellular components that contributes to tissue damage and other diseases such as diabetes mellitus. As reported by Kazeem and Ashafa [67], hydroxyl radicals are highly reactive in causing enormous biological damage to any living cell; however, it is evident that this untoward effect may be mitigated by $P$. prunelloides since the extracts even showed superior effectiveness than gallic acid (Table 1). DPPH assay is an important method at assessing the antioxidant potential of medicinal plants, the ability of the extract to scavenge this radical signifies the potential to reduce the stable free radical of DPPH to the yellow coloured diphenylpicrylhydrazine [68] and this indicates the capacity to inhibit oxidative stress, which consequently might ameliorate type II diabetes and its associated complications. Humans are unable to eliminate iron released from the breakdown of transfused red blood cells leading to excessive deposition in the liver, spleen and endocrine organs which ultimately causes tissue damage leading to various complications such as heart failure, endocrine abnormalities like diabetes, liver failure hypothyroidism and eventual death $[69,70]$. The ability of the extracts particularly aqueous-ethanol to inhibit metal ions (Table 1) and successfully interfere with the formation of ferrous-ferrozine complex is wonderful as noted in the report of Enein et al. [71] assist in removal of toxic ions formed, resulting in abnormalities that could pave way for onset of diabetes mellitus [70].

Secondary metabolites are one important factors contributing to the medicinal value of a plant [72]. The differences in the percentage composition of each phytochemicals in the screened extracts could be attributed to the extractant used, which might probably be due to degrees in polarity. The presence of phytochemicals such as saponins, tannins, terpenoids, flavonoids and phenolics in some or all the extracts may be responsible for the inhibitory potential of the plant on the studied enzymes and parameters. Numerous studies had established and confirmed the pharmacological attributes of these phytoconstituents as antioxidants, antidiabetic, antimalarial, antimicrobials etc. [51,52,53,73,74]. Saponins provide several health benefits such as reducing cholesterol levels in the intestinal tract and inhibiting the proliferation of cancer cells, therefore, help in mitigating against obesity and antimutagenicity [22]. Tannins have been reported to help in Alzheimer and diabetes conditions [75]. Flavonoids and phenolic acids, being the largest classes of plant phenolics and are known to possess good antioxidant activity both in vitro and in vivo experiments [76]. The detection of flavonoids only in ethanol extract coupled with the exhibited antihyperglycemic potency corroborates previous similar submissions [52,53,77] which reports flavonoids due to ease of scavenging superoxide anions [78] as effective antioxidants, antidiabetic and cytotoxic phytoconstituents.

\section{Conclusion}

Overall, the result from this investigation provides information indicating $P$. prunelloides as a possible antidiabetic plant. It elicited its action through inhibition of hydrolyzing enzymes ( $\alpha$-amylase and $\alpha$-glucosidase). 
Additionally, the mitigation of free radicals by the various extract of the plant is suggestive of the use of the plant as a promising anti- oxidative agent. These findings also support the traditional use of Pentanisia prunelloides in the management of diabetes mellitus and further document the use of the plant in the eastern Free State Province of South Africa for this purpose and numerous other illnesses.

\section{Acknowledgements}

The authors are grateful to the National Research Foundation of South Africa for funding the Master's degree research of Ms. Makhubu. We also thank the UFS-DRD for financial support (211427604) and for granting Dr. FO Balogun a postdoctoral fellowship tenable at phytomedicine and phytopharmacology research group.

\section{Statement of Competing Interest}

The authors declare no conflicting interest

\section{References}

[1] Altan, V.M, "The pharmacology of diabetic complications", Current Medicinal Chemistry, 10. 1317-1327. 2003.

[2] IDF, IDF Diabetes Atlas. 1st edition. Brussels, Belgium: International Diabetes Federation, 2000

[3] W.H.O, "World Health Statistics". World Health Organization, 2015.

[4] Brownlee, M, "The pathobiology of diabetic complications: A unifying mechanism”, Diabetes, 54. 1615-1625. 2005.

[5] Niedowicz, D.M. and Daleke, D.L, "The role of oxidative stress in diabetic complications”, Cell Biochemistry and Biophysics, 43. 289-330. 2005

[6] Babu, V.L. and Gowri, R, "Evaluation of antioxidant activity of Beta vulgaris root extract in rats", Asian Journal of Chemistry, 22(5). 3385-3389. 2010.

[7] Bischoff, H. "Pharmacology of glucosidase inhibitor", European Journal of Clinical Investigation, 24(3). 3-10. 1994.

[8] Fujisawa, T., Ikegami, H., Inoue, K., Kawabata, Y. and Ogihara, T, "Effect of two alpha-glucosidase inhibitors, voglibose and acarbose, on postprandial hyperglycemia correlates with subjective abdominal symptoms”, Metabolism, 54. 387-390. 2005.

[9] Shai, L.J., Masoko, P., Mokgotho, M.P., Magano, S.R., Mogale, A.M., Boaduo, N. and Ellof, J.N, "Yeast alpha-glucosidase inhibitory and antioxidant activities of six medicinal plants collected in Phalaborwa, South Africa”, South African Journal of Botany, 76. 465-470. 2010.

[10] Deshpande, M.C., Venkateswarlu, V., Babu, R.K., and Trived, R.K, "Design and evaluation of oral bioadhesive controlled release formulations of miglitol, intended for prolonged inhibition of intestinal alpha-glucosidases and enhancement of plasma glycogen like peptide-1 levels", International Journal of Pharmaceutics, 380. 16-24. 2009.

[11] Van Wyk, B.E., Van Oudtshoorn, B. and Gericke, N, "Medicinal plants of South Africa," Revised and expanded edition, Briza Publications, Pretoria, 2009.

[12] Moteetee, A. and van Wyk, B.E, "The medical ethnobotany of Lesotho: a review”, Bothalia, 41. 209-228, 2011.

[13] Hutchings, A., Scott, A.H., Lewis, G. and Cunningham, A, Zulu Medicinal Plants, Natal University Press, Pietermaritzburg, 1996.

[14] Neuwinger, H.D. African Traditional Medicine - a Dictionary of Plant Use and Applications, Medpharm Scientific Publishers, Stuttgart, 2000.

[15] Van Wyk, B.E., Van Oudtshoorn, B. and Gericke, N, Medicinal plants of South Africa, 2nd Edition, Tien Wah Press, Singapore, 2000.
[16] Madikizela, B, Ndhlala, A.R., Finnie, J.F. and Van Staden, J, "Ethnopharmacological study of plants from Pondo land used against diarrhea”, Journal of Ethnopharmacology, 141. 61-71. 2012.

[17] Steenkamp, V, "Traditional herbal remedies used by South African women for gynaecological complaints”. Journal of Ethnopharmacology, 86. 97-108. 2003.

[18] Bisi-Johnson, M.A., Obi, C.L., Kambizi, L. and Nkomo, M, “A survey of indigenous herbal diarrhoeal remedies of O.R. Tambo district, Eastern Cape Province, South Africa”, African Journal of Biotechnology, 9(8). 1245-1254. 2009.

[19] Smith, A, Contribution to the South African Materia Medica. Juta, Cape Town, 1895.

[20] Kaidoo, T.L., Veale, D.J., Havlik, I, Rama, B.B, "Preliminary screening of plants used in South Africa as traditional herbal remedies during pregnancy and labour”, Journal of Ethnopharmacology, 55. 185-191. 1997.

[21] Yff, B.T.S., Lindsey, K.L., Taylor, M.B., Erasmus, D.G. and Jager, A.K, "The pharmacological screening of Pentanisia prunelloides and isolation of antimicrobial compound palmitic acid”, Journal of Ethnopharmacology, 79. 101-107. 2002.

[22] Madikizela, B., Ndhlala, A.R., Finnie, J.F. and Van Staden, J, “In vitro antimicrobial activity of extracts from plants used traditionally in South Africa to treat tuberculosis and related symptoms”, Evidence-Based Complementary and Alternative Medicine, 8. March 2013.

[23] Muleya, E., Ahmed, A.S., Sipamla, A.M., Mtunzi, F.M. and Mutatu, W, "Pharmacological properties of Pomaria sandersonii, Pentanisia prunelloides and Alepidea amatymbica extracts using in vitro assays", Journal of Pharmacognosy and Phytotherapy, 6(1). 1-8. 2015.

[24] Mpofu, S.J., Msagati, T.A.M. and Krause, R.W.M "Synthesis of liposomes using $\alpha$ - phosphotidycholine and metabolites obtained from Elephantorrhiza elephantina and Pentanisia prunelloides", African Journal of Biotechnology, 13. 1402-1412, 2014.

[25] Liu, F., Ooi, V.E.C. and Chang, S.T, "Free radical scavenging activity of mushroom polysaccharide extracts”, Life Sciences, 60. 763-771. 1997.

[26] Oboh, G. and Rocha, J.B.T, "Polyphenols in red pepper [Capsicum annuum var. aviculare (Tepin)] and their protective effect on some pro-oxidants induced lipid peroxidation in brain and liver”, European Food Research and Technology, 225. 239-247. 2006.

[27] Saha, M.R., Hasan, S.M.R., Akter, R., Hossin, M.M., Alam, M.S. and Alam, M.A. et al. "In vitro free radical scavenging activity of methanol extract of the leaves of Mimusops elengi Linn", Bangladesh Journal of Veterinary Medicine, 6. 197-202. 2008.

[28] Dorman, H.T.D., Kosar, M., Kahlos, K., Holm, Y. and Hittunen, R, "Antioxidant properties and composition of aqueous extracts from Mentha species, hybrids, varieties and cultivars", Journal of Agricultural and Food Chemistry, 51. 4563-4569. 2003.

[29] Adisakwattana, S., Charoenlertkul, P. and Yibchok-Anun, S, "Alpha-glucosidase inhibitory activity of cyanidin-3-galactoside and synergistic effect with acarbose", Journal of Enzyme Inhibition and Medicinal Chemistry, 24. 65-69. 2009.

[30] Ali, H., Houghton, P.J. and Soumyanath, A, “ $\alpha$-Inhibitory activity of some Malaysian plants used to treat diabetes; with reference to Phyllanthus amarus", Journal of Ethnopharmacology, 107. 449-455. 2006.

[31] McCue, P.P. and Shetty, K, "Inhibitory effects of rosmarinic acid extracts on porcine pancreatic amylase in vitro", Asia Pacific. Journal of Clinical Nutrition, 13. 101-106. 2004.

[32] Trease, and Evans, W.C. Pharmacognosy, 14th Edition, W.B Saunders Company, Ltd., London, 1996.

[33] Sofowora, Medicinal plants and traditional Medicine in Africa, Spectrum books Ltd., Ibadan, pp. 289, 2006.

[34] Harborne, J.B. Phytochemical Methods, Chapman and hall Ltd., London: U.K, 621 49-188, 1973.

[35] Obadoni, B.O. and Ochuko, P.O, "Efficacy of the crude and comparative of some homeostatic plants in Edo and Delta states of Nigeria-Global”, Journal of Pure and Applied Sciences, 455-459. 2001.

[36] Miean, K.H. and Mohamed, S, "Flavonoid (myricetin, quercetin, kaempferol, luteolin, and apigenin) content of edible tropical plants”, Journal of Agricultural and Food Chemistry, 49. 3106-12. 2001. 
[37] Lin, J.Y. and Tang, C.Y, "Determination of total phenolic and flavonoid contents in selected fruits and vegetables, as well as their stimulatory effect on mouse splenocyte proliferation”, Food Chemistry Journal, 101. 140-7. 2007.

[38] Singleton, V.L., Orthofer, R. and Lamuela-Raventos, R.M, "Analysis of total phenols and other oxidation substrates and antioxidants by means of Folin-Ciocalteu reagent oxidants and antioxidants”, Methods in Enzymology, 299. 152-178. 1999.

[39] Wolfe, K., Wu, X. and Liu, R.H, “Antioxidant activity of apple peels”, Journal of Agriculture and Food Chemistry, 51. 609-614. 2003.

[40] Bailey, C.J, "Potential new treatments for type 2 diabetes”, Trends in Pharmacological sciences, 21. 259-265. 2000.

[41] Ortiz-Andrade, R.R., Garcia-Jimenez, S., Castillo-Espana, P., Ramirez-Avila, G., Vilalbo-Molina, R. and Estrada-Soto, S, "Alpha-glucosidase inhibitory activity of the methanolic extract from Tournefortia hartwegiana: an anti-hyperglycemic agent”, Journal of Ethnopharmacology, 109. 48-53. 2007.

[42] Rhabasa-Lhoret, R. and Chiasson, J.L, “Alpha-glucosidase inhibitors” 3rd Ed. International Textbook of Diabetes Mellitus, John Wiley, UK, 2004.

[43] Nolte, M.S. and Karam, J.H, Pancreatic hormones and antidiabetic drugs, In: Basic and Clinical Pharmacology, 8th edition. Katzung B.G. Lange Medical Books. McGraw-Hill, San Francisco. USA, pp. 711-734, 2001.

[44] Kim, Y.M., Jeong, Y.K., Wang, M.H., Lee, W.Y. and Rhee, H.I, "Inhibitory effects of pine bark extract on alpha-glucosidase activity and postprandial hyperglycemia”, Nutrition, 21. 756-61. 2005.

[45] Balogun, F.O. and Ashafa, A.O.T, “Aqueous root extract of Dicoma anomala (Sond.) extenuates postprandial hyperglycaemia in vitro and its modulation on the activities of carbohydratemetabolism enzymes in streptozotocin -induced diabetic Wistar rats”, South African Journal of Botany, 112. 102-112. 2017.

[46] Apostolidis, E., Kwon, Y.I. and Shett, K, "Inhibitory potential of herb, fruit, and fungal- enriched cheese against key enzymes linked to type 2 diabetes and hypertension”, Innovative Food Science and Emerging Technologies, 8. 46-54. 2007

[47] Cheplick, S., Kwon, Y.I., Bhowmik, P. and Shetty, K, "Phenolic-linked variation in strawberry cultivars for potential dietary management of hyperglycemia and related complications of hypertension”, Bioresource Technology, 101. 404-413. 2010.

[48] Ogunwande, I.A., Matsui, T., Fijise, T. and Matsumoto, K, " $\alpha$-Glucosidase inhibitory profile of Nigerian medicinal plants in immobilized assay system”, Food Science and Technology Research, 12(2). 169-172. 2007

[49] Toda, M., Kawabata, J. and Kasai, T, “ $\alpha$-Glucosidase inhibitors from Clove (Syzgium aromaticum)", Bioscience Biotechnololgy and Biochemistry, 64. 294-298. 2000.

[50] Lu, X., Ross, C.F., Powers, J.R., Aston, D.E. and Rasco, B.A "Determination of total phenolic content and antioxidant activity of garlic (Allium sativum) and elephant Garlic (Allium ampeloprasum) by attenuated total reflectance-Fourier Transformed Infrared Spectroscopy”, Journal of Agriculture and Food Chemistry, 59(10). 5215-5221. 2011.

[51] Vinayagam, R. and $\mathrm{Xu}, \mathrm{B}$, “Antidiabetic properties of dietary flavonoids: a cellular mechanism Review”. Nutrition Metabolism, 12. 60. 2015

[52] Balogun, F.O. and Ashafa, A.O.T, "Cytotoxic, kinetics of inhibition of carbohydrate-hydrolysing enzymes and oxidative stress mitigation by flavonoids roots extract of Dicoma anomala (Sond.)”, Asian Pacific Journal of Tropical Medicine, 11(1). 24-31. 2018.

[53] Balogun, F.O. and Ashafa, A.O.T, "Oxidative stress mitigation, kinetics of carbohydrates enzymes inhibition and cytotoxic effects of flavonoid-rich leaf extract of Gazania krebsiana (Less.): in vitro evaluations”, Asian Pacific Journal of Tropical Biomedicine, 8(1). 52-58. 2008.

[54] Kunyanga, C., Kathenya Imungi, J., Okoth, M., Momanyi, C., Biesalski, H. and Vellingiri, V, “Antioxidant and antidiabetic properties of condensed tannins in acetonic extract of selected raw and processed indigenous food ingredients from Kenya”, Journal of Food Science, 76(4). 2011

[55] Ravichandiran, V., Nirmala, S. and Nazeer Ahamed, K.F.H, "Protective effect of tannins from Ficus racemosa in hypercholesterolemia and diabetes induced vascular tissue damage in rats”, Asian Pacific Journal of Tropical Medicine, 367-373. 2012.

[56] Morada, N.J., Metillo, E.B., Uy, M.M. and Oclarit, J.M, "Toxicity and hypoglycemic effect of tannin-containing extract from the mangrove tree Sonneratia alba Sm”, Bulletin of Environment, Pharmacology and Life Sciences, 5(6). 58-64. 2016.

[57] Kwon, Y.I., Apostolidis, E., Kim, Y.C. and Shetty, K, "Health benefits of traditional corn, beans and pumpkin: in vitro studies for hyperglycemia and hypertension management”, Journal of Medicinal Food, 10. 266-275. 2007.

[58] Mayur, B., Sandesh, S., Shruti, S. and Sung-Yum, S, “Antioxidant and $\alpha$-glucosidase inhibitory properties of Carpesium abrotanoides L”, Journal of Medicinal Plants Research, 4. 1547-1553. 2010.

[59] Khatoon, M., Islam, E., Islam, R., Rahman, A.A., Alam, H.M.K., Khondkar, P., Parvin, S, "Estimation of total phenol and in vitro antioxidant activity of Albizia procera leaves", BMC Research Notes, 6. 121. 2013

[60] Suwalsky, M. and Avello, M, “Antioxidant capacity of Ugni molinae fruit extract on human erythrocytes: An in vitro study", Journal of Membrane Biology, 247. 703-712. 2014.

[61] Amic, D., Davidovic-Amic, D., Beso, D. and Trinajstic, N, "Structure-radical scavenging activity relationship of flavonoids", Croatica Chemica Acta, 76. 55-61. 2003.

[62] Duarte, T.L., Lunec, J, "Review: When is an antioxidant not an antioxidant? A review of novel actions and reactions of vitamin C”, Free Radical Research, 39. 671-686. 2005.

[63] Deutschländer, M.S., van de Venter, Roux, S. and Lall, N, "Hypoglycaemic activity of four extracts traditionally used in South Africa for diabetes”, Journal of Ethnopharmacology, 124. 619-624. 2009.

[64] Dai, J. and Mumper, R, "Plant phenolics: extraction, analysis and their antioxidant and anticancer properties”, Molecules, 15(10). 7313-7352. 2010.

[65] Giacco, F. and Brownlee, M, “Oxidative stress and diabetic complications”, National Institutes of Health, 107(9). 1058-1070. 2011.

[66] Khan, R.A., Khan, M.R., Sahreen, S. and Ahmed, M, "Evaluation of phenolic contents and antioxidant activity of various solvent extracts of Sonchus asper (L.) Hill”, Chemistry Central Journal, 6. 12. 2012.

[67] Kazeem, M.I. and Ashafa, A.O.T, "In-vitro antioxidant and antidiabetic potentials of Dianthus basuticus Burtt Davy whole plant extracts”, Journal of Herbal Medicine, 5(3). 158-164. 2015

[68] Wettasinghe, M. and Shahidi, F, "Scavenging of reactive-oxygen species and DPPH free radicals by extracts of borage and evening primrose meals”, Food Chemistry, 70. 17-26. 2000.

[69] Loukopoulos, D, "Combined therapy with deferiprone and desferrioxamine in thalassemia major”, Journal of Hematology, 90. 1305-1305. 2005.

[70] Taher, H. Isma'eel, and Cappellini, M.D, “Antioxidant activity of algal extracts on lipid peroxidation. Thalassemia intermedia: revisited”, Journal of Medical Science, 37. 12-20. 2006.

[71] Enein, A.A.M., El Baz, F.K., El-Baroty, G.S., Youssef, A.M. and Abd El-Baky, H.H, "Antioxidant activity of algal extracts on lipid peroxidation”, Journal of Medical Sciences, 611(3). 87-98. 2003.

[72] Edeoga, H.O., Okwa, D.E. and Mbaebie, B.O, "Phytochemical constituents of some Nigerian medicinal plants", African Journal of Biotechnology, 4. 685-688. 2005.

[73] Kumar, S., Gupta, A. and Pandey, A.K, "Calotropis procera root extract has capability to combat free radical mediated damage", ISRN Pharmacology, 8. 2013.

[74] Salvamani, S., Gunasekaran, B., Shaharuddin, N.A., Ahmad, S.A. and Shukor, Y, “Antiartherosclerotic effects of plant flavonoids”, Biomed Research International, 14. 2014

[75] Ono, K., Hasegawa, K., Naiki, H., and Yamada, M, "Antiamyloidogenic activity of tannic acid and its activity to destabilize Alzheimers $\beta$-amyloid fibrils in vitro", Biochimica et Biophysica Acta, 1690. 193-202. 2004.

[76] Kasote, D.M., Katyare, S.S., Hegde, M.V. and Bae, H, "Significance of Antioxidant Potential of Plants and its Relevance to Therapeutic Applications”, International Journal of Biological sciences, 11(8). 982-991. 2015. 
[77] Robak, J. and Gryglewski, R.J, "Flavonoids are scavengers of superoxide anions", Biochemical Pharmacology 37. 837-841. 1988.
[78] Cook, N.C. and Samman, S, "Flavonoids chemistry, metabolism, cardioprotective effects, and dietary sources", Journal of Nutritional Biochemistry, 7. 66-76. 1996.

(C) The Author(s) 2019. This article is an open access article distributed under the terms and conditions of the Creative Commons Attribution (CC BY) license (http://creativecommons.org/licenses/by/4.0/). 